\title{
An Assessment of Social and Environmental Implications of Agricultural Water Pollution in Nuwara Eliya
}

\author{
H.P. Henegama, N.D.K. Dayawansa ${ }^{1 *}$ and Saliya De Silva ${ }^{2}$ \\ Postgraduate Institute of Agriculture \\ University of Peradeniya \\ Sri Lanka
}

\begin{abstract}
Agriculture-related water pollution is a serious concern in major agricultural areas in the country. This study was conducted with the objective of reviewing the existing situation of agricultural activities and their implications on the environment and society in Nuwara Eliya Divisional Secretariat Division. A questionnaire survey with 50 households in 15 Grama Niladhari divisions was conducted in the year 2008 for gathering information on nature of fertilizer and agro-chemical use, land management practices, condition of water sources and socio-economic and environmental implications of water pollution. The study revealed that the majority of sample farmers in the study area are engaged in unacceptable agricultural activities. Root crops and vegetables are mainly cultivated at two to four times per year without proper soil conservation practices. The fertilizer and pesticide rates applied by the farmers are highly variable but in some occasions about 10 times higher than the rates recommended by the Department of Agriculture. The riparian vegetation has been cleared in many places to gain land for cultivation, exposing the streams to agricultural runoff. It was revealed that drinking water sources of $45 \%$ of the households surveyed are located in highly vulnerable areas for agricultural pollution. The main socioeconomic issues observed include loss of family income, health issues, psychological effects and effect on family wellbeing. The environmental implications observed include land degradation, soil erosion, sedimentation, water contamination and degradation of aesthetic value. In addition, the study identified that the organizations working on environment and water resources do not collaborate with each other and long term measures have not been taken to control the agricultural water pollution. Awareness creation on agricultural pollution and associated environmental issues is of key importance. A strong collaboration should be developed within the institutions involved in agriculture, environmental management and administrative activities in the area to formulate a sustainable agricultural system in the Nuwara Eliya district.
\end{abstract}

Keywords: Agriculture, water pollution, environment, socio-economic implications

\section{INTRODUCTION}

Up country of Sri Lanka is famous for cultivation of exotic vegetables. Production of vegetables such as beet, leeks, and potato comes with a huge social and environmental cost

\footnotetext{
Department of Agricultural Engineering, Faculty of Agriculture, University of Peradeniya Department of Agricultural Extension, Faculty of Agriculture, University of Peradeniya, Peradeniya, Sri Lanka Corresponding author: dammid@pdn.ac.lk
} 
as a result of heavy usage of fertilizers and agro-chemicals. Being in the headwater areas for important rivers in the country, excess accumulation of these contaminants in the soil, transport of pollutants with sediments and subsequent release to the water sources are serious concerns (Wijewardena, 1998). Water quality can be seriously deteriorated by agriculture through soil application of fertilizers and manure in large quantities more than the recommended levels (Rajakaruna et al., 2005). The agricultural runoff, which comes from non-point sources, consists of pesticides, nutrients, suspended solids and organic materials. Soil erosion and sedimentation of water bodies is another adverse effect due to the improper agricultural activities in Sri Lanka (Dayawansa, 2006). The major types of fertilizers and pesticides used in Sri Lanka are sulphate of ammonia, urea, rock phosphate, muriate of potash, triple super phosphate and mixed fertilizers and Propanil and MCPA (Mubarak, 2000) respectively.

Many studies have identified that heavy use of fertilizers and pesticides in Nuwara Eliya area more than the recommended levels and their impacts on the environment specifically, on water resources. According to Rajakaruna et al. (2005) there were high levels of nitrate and basic cations in well-water in crop fields compared to the same in forest areas in Nuwara Eliya. As reported by Premarathna et al. (2005) there was high cadmium (Cd) concentration $(1.96 \mathrm{mg} / \mathrm{kg})$ in the tested soil samples of Kandapola. Well-water sample analysis in Nuwara Eliya revealed that, many samples have high nitrate values making such water unsafe for human drinking (Amarasiri, 2007). Removal of productive fertile top soil and eutrophication in areas such as Nanu Oya, Lake Gregory, and Barrack plain are some other problems related to soil erosion and sedimentation identified in Nuwara Eliya district (UDA, 2004). Ranatunga and Ranasignhe (2007) reported that most of the traditional water sources in Nuwara Eliya district are depleted or compelled to be abandoned due to pollution.

It is a well known fact that Lake Gregory in Nuwara Eliya district is polluted due to several reasons including discharge of human and domestic waste and chemicals from agricultural lands. The catchment of Gregory Lake has intensive vegetable cultivation and high population density and therefore high amount of urban wastewater and sediments come through runoff (Amarathunga et al., 2010). The fertile sediments which are resulted by soil erosion and transported from the tributaries of the Gregory Lake via agricultural fields encourage the aquatic plant growth (UDA, 2004). Water quality data of Lake Gregory show the presence of nitrogenous and phosphorus compounds, iron etc. (UDA, 1996). According to De Silva (2009), the upcountry estate sector commonly has outbreaks of communicable diseases like hepatitis, typhus, diarrhoea, skin diseases, mainly resulted from consumption of polluted water.

In considering the socio economic impacts in estate sector in Nuwara Eliya, the polluted water has a greater impact on estate women and their daily activities. Lifting and carrying 10 - 15 liters of heavy clay/plastic pots cause serious health hazards to women in their old ages (De Silva, 2009). According to Mubarak (2000), an estimate of Rs. 2700 million in 1992 was made for the economic costs of water pollution in Sri Lanka especially for health impacts, loss of wages, treatment costs etc.

With this background, the main aim of this study was to assess the socioeconomic and environmental implications of agricultural water pollution in Nuwara Eliya. It was attempted to 
- investigate the existing situation of farm plots, water sources, agricultural practices, soil conservation, agrochemical usage of farmers and its possible threats for the environment

- assess the possible socio-economic and environmental implications of polluted water resulting from agricultural activities

- $\quad$ assess the role of institutions in agricultural water management in the study area

\section{MATERIALS AND METHODS}

The study area was located in 15 Grama Niladari (GN) divisions in Nuwara Eliya Divisional Secretariat (DS) division. Fifty (50) household units located within these 15 GN divisions were randomly and purposely (based on preliminary data collection) selected to collect data on agricultural practices and possible socio-economic and environmental implication related to water pollution. The distribution of households of the sample according to the GN divisions is given in the Table 1.

Table 1. Distribution of the households (HH) of the sample in GN divisions

\begin{tabular}{cc}
\hline GN Division & No. of HH \\
\hline Senliyanate & 2 \\
Brook Side & 3 \\
Herath pura & 1 \\
Ruwan Eliya & 6 \\
Black pool & 7 \\
Sandathenna & 8 \\
Kalukele & 1 \\
Nuwara Eliya & 8 \\
Hawa Eliya & 2 \\
Kuda Oya & 1 \\
Magasthota & 2 \\
Boralanda & 5 \\
Buluwala & 1 \\
Kande Ela & 1 \\
Kuda Oya & 2 \\
Total & 50 \\
\hline
\end{tabular}

This study mainly used primary data collected through a field survey conducted in 2008 using a questionnaire. The data on amount of fertilizer and agrochemical applications, location of water sources, socioeconomic issues were collected. Pollution sources, nature of land preparation, fertilizer application, possible threats of these activities on water resources were observed during the field visits. Water quality and other related data were collected from secondary sources; mainly the past studies conducted by other researchers in the study area. Data were analyzed by SPSS and MS Excel software. 


\section{RESULTS AND DISCUSSION}

\section{a) Characteristics of farmers and their sources of water}

The average family size of the sample is five. Ratio between male to female is approximately one to one. The average age of the head of the family is about 49 years. The age distribution of the sample shows that the majority of them are in the age category of $20-40$ years, who can engage in agricultural activities. Majority of the household heads (56\%) has obtained secondary level education, thus, they should have knowledge on agricultural pollution and its implications on environment. About $30 \%$ of the members of the sample, both males and females, are engaged in farming as their primary occupation. The average monthly income of the sample is Rs. 20,327 which is slightly above the average Sri Lankan monthly household income of Rs. 20,048 (Department of Census and Statistics, 2007). About 46\% of the sample is above the average monthly household income in Sri Lanka. The average income of the family increases with increasing family size possibly due to increasing number of income generators.

Fig. 1 and 2 present the drinking and irrigation water sources used by the sample households. The statistics show that $50 \%$ of the sample households use their own well as the drinking water source. Rest of the households use streams, springs, pipe borne water and common wells as their main drinking water source. Streams (39\%) and own wells (35\%) are the main water sources used for irrigation by the respondents. In addition, ponds, rivers, rainwater, common taps and natural springs are used as irrigation water sources. In most cases, these wells are located very close proximity to or within the vegetable fields having easy access to inflow of runoff water from vegetable fields. The study reveals that $45 \%$ of drinking water sources are located less than $10 \mathrm{~m}$ distance from the vegetable fields which is categorized as vulnerable for contamination. According to the farmers' perception received at survey, there is a great possibility of this shallow well water being contaminated with leached nutrients and heavy metals released from fertilizer and agro-chemicals. Streams also receive runoff water coming from the vegetable fields.

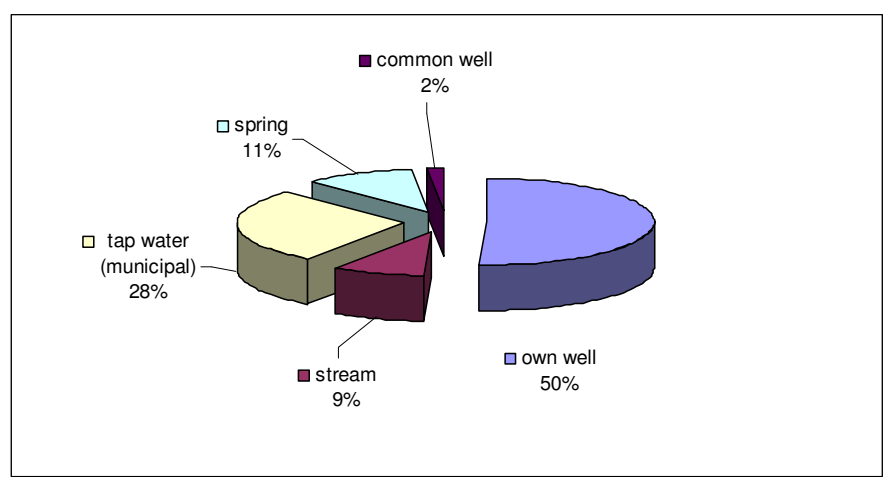

Fig. 1. Drinking water sources used by the sample households 


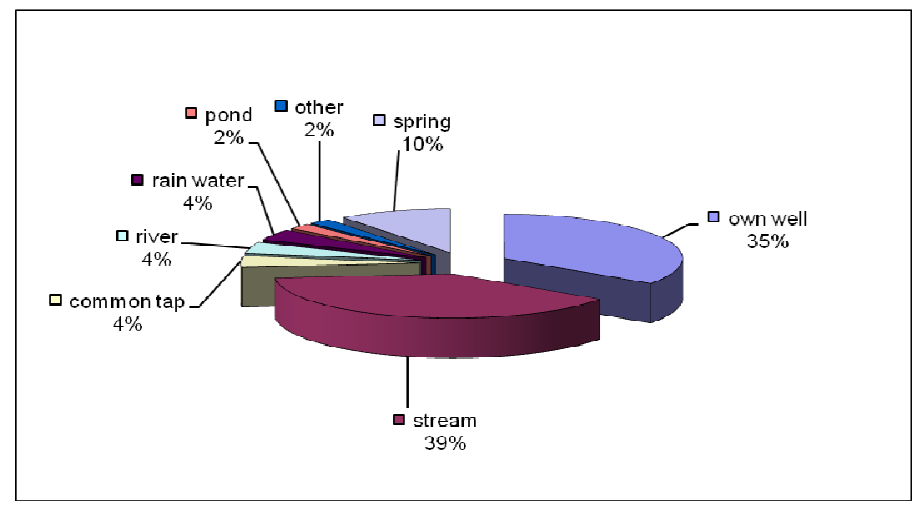

Fig. 2. Water sources used for irrigation by the sample farmers

Riparian vegetation plays a major role in trapping sediments in runoff and associated pollutants (Vigiak et al., 2007). They are helpful in absorbing nutrients and heavy metals in the soil. This will lead to reduce the input of these pollutants to the stream water. However, it was observed that the lands in the riparian zone of small streams and water bodies are encroached and used for agricultural purposes. About $72 \%$ of the area investigated was under residential and agricultural category. As revealed in the study, majority of the households have land with average land size of 0.4 acres. According to the survey, 57\% of the respondents own their lands while $9 \%$ are under encroached lands. These lands are encroached from the reservation areas and it shows the vulnerability of streams and other important land features for pollution and degradation. Cultivation along the reservation areas of streams is a common practice in Nuwara Eliya. There is a great possibility to contaminate the water bodies by fertilizers and pesticides applied to the cultivations at banks of such water bodies.

\section{b) Agricultural activities causing water pollution}

The study area is an intensive agricultural area where farmers grow three or four crops per year in their lands. Potato and exotic vegetables are the predominant crops grown in this region throughout the year. The main crops grown include potato, beet, carrot, cabbage, lettuce, leeks and cut flower. Total root crops cultivated are about $50 \%$ out of the total crops cultivated throughout the year. With respect to soil conservation, majority (61\%) of the lands are with no soil conservation measures. Those farmers have cultivated their crops in inclined lands without considering much about soil erosion. Cattle, goats and poultry are the most commonly reared animals by farmers in study area. About $90 \%$ of the respondent farmers rear backyard poultry. Some farmers use the excreta of these animals as fertilizers while others discharge those into the environment since some of them do not want to use those as fertilizers due to bad odour and lack of awareness.

Common fertilizers applied by the farmers in the study area are muriate of potash (MOP), NPK (fertilizer mixture with nitrogen, phosphorus and potassium), urea, triple super phosphate (TSP) and organic manure such as cow dung, poultry manure, and litter. Some farmers apply a combination of all fertilizers as a mixture. Fig. 3 presents the type of fertilizers applied by the respondent farmers. 


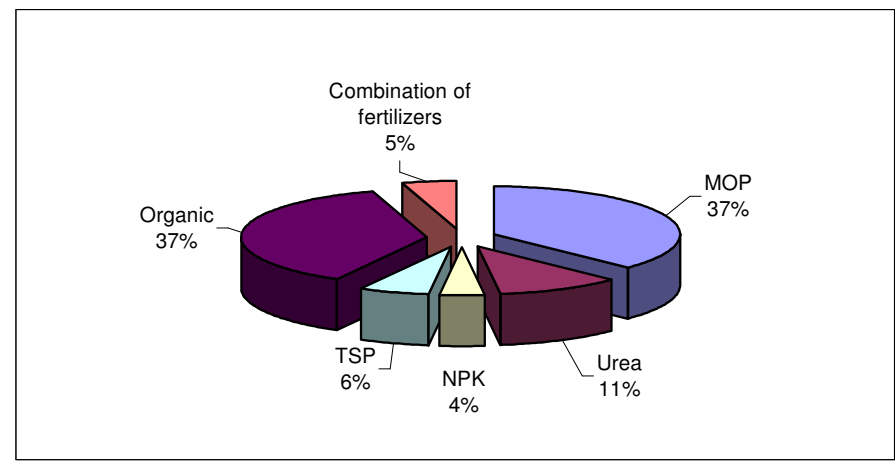

Fig. 3. Fertilizers applied by farmers in the study area (\%)

The average application rates of selected fertilizers were compared with the recommended fertilizer application rates of the Department of Agriculture (DOA) (DOASL, 2006). The fertilizers applied by the farmers of surveyed area were grouped into three main categories as Muriate of Potash (MOP), Urea and Triple Super Phosphate (TSP). Fig. 4 shows the average application rates (kg/acre) of fertilizers (MOP/Urea/TSP) with the standard rates of DOA for the selected crops of potato, carrot, beet, leeks and cabbage. Since potato is a root crop and it does not need high levels of nitrogen, farmers prefer to apply leaf manure or organic fertilizers to fulfil the nitrogen demand.

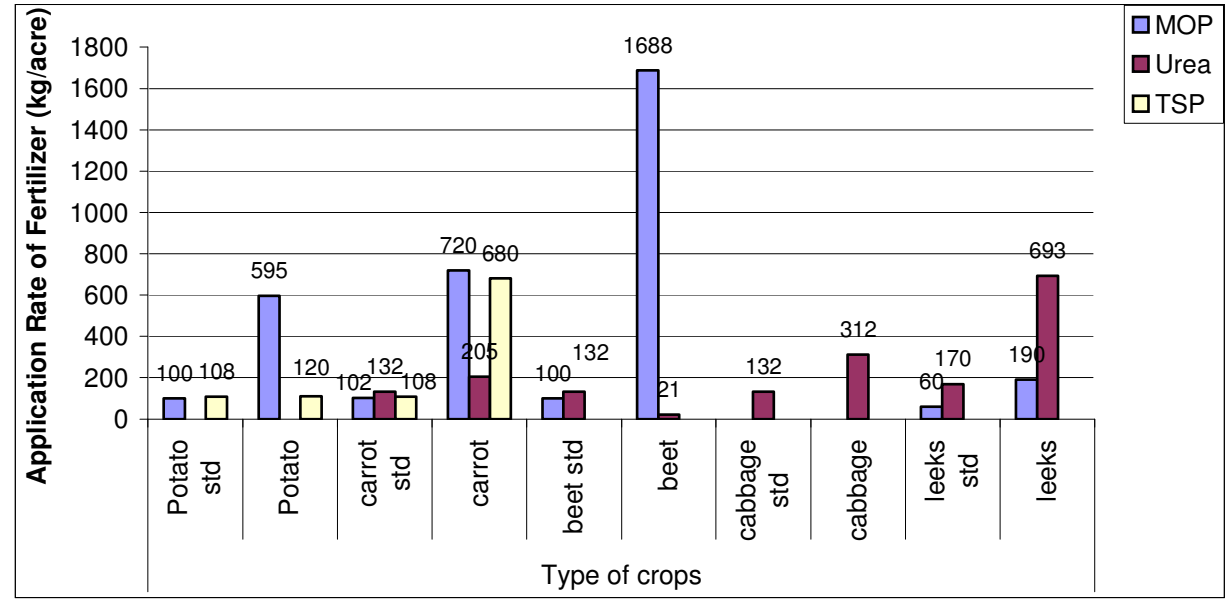

Fig. 4. Average application rates and recommended rates (std) of fertilizers

As shown in Fig. 4. the fertilizers applied by the farmers in the survey area are many times higher than the recommended standard application rate of the Department of Agriculture due to over application of fertilizers by farmers neglecting or unawareness of the standard recommended application rates by the DOA. Accordingly, average application rates of MOP (Muriate of Potash) is 495\%, 606\%, 1588\% and 217\% higher than the standard application rate of MOP by Department of Agriculture for potato, carrot, beet and leeks, respectively. Beet crop has the highest over application rate as about 16 times more than the recommended 
rate. The average application rate of TSP is $12 \%$ and $530 \%$ higher than the standard application rate of TSP by the Department of Agriculture for potato and carrot, respectively. The average application rates of Urea is $55 \%, 136 \%$ and $308 \%$ higher than the standard application rate of Urea by the Department of Agriculture for Carrot, Cabbage and Leeks, respectively. Mubarak (2000) explains that the majority of the farmers apply agrochemicals higher than the recommended quantities and the trend of high nitrogen and phosphorus fertilizer consumption is expected to increase the levels of nutrients in surface runoff from farmlands leading to eutrophication of receiving water bodies.

The main pesticides used in study area were Mancozeb, Maneb, Propineb, Chlorothanonyl, Chloropyrifos and Carbofuran during the year of survey 2008. They are under the categories of fungicides (Mancozeb, Maneb, Propineb, and Chlorothanonyl) and insecticides (Chloropyrifos and Carbofuran). Mancozeb is used on a wide variety of food crops, including fruits, vegetable crops, field crops, grapes, and ornamental plants as a broadspectrum fungicide used in agriculture. Maneb is applied for the vegetables, fruits and other field crops (EPA, 2005) and Propineb is mainly applied for potato. About $19 \%$ of the farmers apply Chloropyrifos to their cultivation as an insecticide for vegetables. Mancozeb is applied for most of the vegetables by about $22 \%$ of the farmers. Propineb and Maneb are applied to the field by $30 \%$ and $8 \%$ respectively for potato and vegetables by the sample farmers.

The average application rate of Mancozeb is about $76 \%$ higher than the standard application rate recommended by the DOA (Department of Agriculture, 1997) for potato with an over application of $1360 \mathrm{~g} / \mathrm{hectare} / \mathrm{year}$ with respect to the recommended rate of $1800 \mathrm{~g} / \mathrm{hectare}$ per year. At the same time, average application rate of Propineb for cabbage has increased $21 \%$ more than the recommended application rate by DOA. This includes application of 370 $\mathrm{g} /$ hectare/year more than the recommended rate of $1800 \mathrm{~g} / \mathrm{hectare} /$ year. According to the respondent farmers, these over application rates of fungicides are to protect the crops since they are highly vulnerable to fungal attacks possibly due to the moist weather condition prevailing in the area.

Propineb is a fungicide belongs to the dithiocarbamate group of compounds (FAO, 1980) which is insoluble in water and therefore can flow with water for long distances and remain in water. It is biodegradable as well as photodegradable. Propineb is toxic to mammals, fish and bird. Mancozeb is a fungicide, a member of the ethylene bisdithiocarbamate group of fungicide with risk of human health and environment, which is used in vegetables, fruits and field crops (EPA, 2005). Mancozeb is low soluble in water and therefore can remain in water bodies. Maneb is a member of ethylene bisdithiocarbamate group of fungicides which has potential risk to human health and environment used for the crops of vegetables, ornamental plants and field crops (EPA, 2005). With this background, it is evident that excess application of these chemicals poses a serious threat to the human health and the natural environment including water resources, flora and fauna.

\section{c) Water pollution and its implications}

This study did not analyze water samples for quality parameters, instead used secondary data whenever needed from other studies. Although it is impossible to provide statistics on water quality, it was evident that water resources in the area are under risk of contamination by agricultural pollutants. Over usage of fertilizers tend to accumulate in the soil profile and subsequently transfer to the water sources through hydrological pathways. Use of riparian zones for agricultural purposes too poses a threat on water resources. As revealed by the survey, high percentage of respondents believe that their drinking (42\%) and irrigation (77\%) 
water sources are polluted with agricultural pollutants. They complain that drinking water sources in the area show poor physical qualities such as discoloration, odour, oily appearance at the surface, high suspended solids and chemical taste.

Pollution of water sources in the area is evident in the past research. According to Rajakaruna et al. (2005) higher values of $\mathrm{NO}_{3}$-Nitrogen concentrations are found in well water and it is 2-3 times higher than the WHO standards of $10 \mathrm{mg} / \mathrm{L}$. Ayres and Westcot (1985) considered the acceptable range of Potassium (K) in irrigation water as $0-1.95 \mathrm{mg} / \mathrm{L}$ but all the $\mathrm{K}$ levels in well water in upcountry are higher than $1.95 \mathrm{mg} / \mathrm{L}$ (Rajakaruna et al., 2005). According to Watawala et al. (2009) groundwater and the surface water of the catchment of Lake Gregory are having extremely high risk of contamination by fungicides. Low $\mathrm{pH}$ values than WHO standards were reported in the areas of Magasthota, Shanthipura and Blackpool (Wijewardena, 1998). Amarasekara et al. (2009) stated that high level of phosphorus were recorded (above $75 \mathrm{ppm}$ ) in surface water due to nutrient accumulation in stream water of Kurundu Oya in Nuwara Eliya district. Premarathna et al. (2005) revealed the presence of Cadmium (Cd) in water sources in the areas of Kandapola, Seetha Eliya, Haputale etc. It also revealed high concentrations of soil Cd in Haputale $(3.85 \mathrm{mg} / \mathrm{kg})$ and Kandapola $(1.96 \mathrm{mg} / \mathrm{kg})$ where intensive agriculture is being practiced.

The study identified that $10 \%$ of the sample respondents spend more than 4 hours per day for collecting safe drinking water. About $67 \%$ of the households stated that mothers are responsible for collecting drinking water. Since most of the family members are involved in farming activities, when water is collected from far away places, their productive time will be lost, resulting lower income. The disease occurrence, spending time for polluted water treatment and searching of pure water for drinking etc. create the loss of family income since people have to spend additional time for these beside their income generating activities. Boiling is the main treatment for drinking water and $34 \%$ of the sample spends between Rs. 500-1000/month for this purpose. Further, the government organizations such as Urban Development Authority and Municipal Council also have to pay about Rs. 50 million (SLLRDC, 2010) of money for the cleaning of surface water bodies such as Lake Gregory in Nuwa Eliya to remove sediment.

It was revealed in the investigation that people who are in the reservation area do not aware that they live in the reservation area of a particular water body or a stream. It was observed that $8 \%$ of the households of the sample wash harvested vegetables directly in the nearby water bodies such as streams, rivers while others use well water and other sources. The major environmental impacts identified are land degradation and contamination of water sources by agrochemicals and solid wastes. Farmers have cultivated the crops in the riparian areas and the reservation areas of the water sources in study area. Contamination of the water sources by livestock and poultry waste was also observed. Only $31 \%$ of the households were aware about the need of soil conservation irrespective of the ownership of the land. Study revealed that $2 / 3$ of the surveyed farmers does not apply soil conservation methods. Some farmers explained that even though they know the importance of application of soil conservation methods, they are not in a position to apply those since they are in rented or encroached lands and due to financial incapability (Focus Group Discussions with farmers, 2008). The status of relationship between the application of the land conservation method and ownership of the land was investigated as stated in Table 2. There are no sufficient statistical evidences to say that there is a significant relationship between the ownership of the land and application of land conservation methods by farmers. 
Table 2. Ownership of land and application of soil conservation methods

\begin{tabular}{|c|c|c|c|}
\hline \multirow{2}{*}{\multicolumn{2}{|c|}{ Ownership of land }} & \multicolumn{2}{|c|}{ Soil conservation methods } \\
\hline & & $\begin{array}{l}\text { Application of conservation } \\
\text { methods }\end{array}$ & $\begin{array}{l}\text { Non application of } \\
\text { conservation methods }\end{array}$ \\
\hline \multirow{2}{*}{ own land } & Count & 22 & 9 \\
\hline & $\%$ of Total & 50 & 20 \\
\hline \multirow{2}{*}{$\begin{array}{l}\text { not own } \\
\text { land }\end{array}$} & Count & 6 & 7 \\
\hline & $\%$ of Total & 14 & 16 \\
\hline
\end{tabular}

According to Table 2, majority of the farmers (50\%) do not apply soil conservation methods even though they cultivate in their own lands. The main reason for this can be the lack of awareness about land conservation, poor caring about their lands and economical incapability (focus group discussions with farmers, 2008). Poor awareness creates poor attitudes towards soil conservation measures among farmers. Awareness should be created by continuous communication and interaction with relevant government and non-government organizations. The association between the total cultivated area and the application of land conservation method was investigated by the correlation coefficient method. A poor correlation was identified between application of soil conservation measures and the plot size with the Pearson's correlation coefficient of 0.034 at 0.05 confidence level.

The diseases reported in the study area from 2003 to 2008 are still birth, abortions, premature delivery, infection of kidney, cancers, renal failure, nerve problems, urolithiasis and skin diseases. Past research have shown that these diseases have a considerable link with the agricultural pollutants. Hence, it is needed to further analyse these health issues to identify whether there is a link with the agricultural pollutants

\section{d) Role of institutions in environmental conservation}

Management of water pollution needs an interdisciplinary approach (Gunawardena et al., 2010). It should be a collective effort including government/non-government organizations, politicians, experts of the field and the public mass. The main government organizations, which are directly and indirectly, involved in the activities related to environmental conservation activities are Urban Development Authority, Municipal Council, Department of Agriculture, Department of Agrarian Services, Central Environmental Authority (CEA), National Water Supply and Drainage Board, Department of Irrigation, National Building Research Organization, Disaster Management Centre, Meteorological Department etc. The main tasks of these organizations are listed in Table 3. Table 4 presents the activities of the farmer organizations and other farming related societies in the area. 
Table 3. Environmental related government organizations and their specific activities

\section{Organization $\quad$ Environmental related activities}

Urban Development

Authority

Municipal council

National Water Supply and

Drainage Board

Pradeshiya Sabha (Local

Authority)

Central Environmental

Authority

Department of Irrigation

National Building Research

Organization (NBRO)

Disaster Management Centre

Meteorological Department

Department of Agriculture

Department of Agrarian

Services
Town planning and infrastructure planning in Nuwara Eliya and maintenance of Lake Gregory

Administrative activities within town limits, waste management and maintenance of Lake Gregory and its catchment

Supply water after water treatments ensuring the hygiene mainly for people in town area

Water supply and waste management of people in peripheral area

Enforcement of the environmental regulations

Maintenance of the riparian areas and reservation areas around the water bodies and ensure water supply for cultivation in sustainable way

Monitoring, warning and planning issues related to landslides

Monitoring the activities related to natural disasters, coordinate with other organizations related to natural disasters and take immediate actions in an event of natural disaster

Monitoring, observations the activities related to weather and weather forecasting

Enhance the sustainable practices in agriculture in environmentally friendly manner

Conducting extension activities related to sustainable agricultural development

Table 4. Farmer organizations/ societies in study area and their main activities

\begin{tabular}{ll}
\hline \multicolumn{1}{c}{ Type of the Organization } & \multicolumn{1}{c}{ Main Activities } \\
\hline $\begin{array}{l}\text { NGO based societies } \\
\text { Vegetable, livestock farming }\end{array}$ & $\begin{array}{l}\text { Enhance agricultural activities } \\
\text { Enhance agricultural activities, Marketing of agricultural } \\
\text { societies in the village }\end{array}$ \\
$\begin{array}{l}\text { Farming society, which uses } \\
\text { same stream, water body }\end{array}$ & Water related activities and agricultural activities \\
Society of Govi Jana Sewa & Enhance agricultural activities, conserve environment \\
\hline
\end{tabular}


There are several non-government organizations too in Nuwara Eliya district which are involved in environmental conservation activities as revealed in the survey (Eg: Palm Foundation, Sri Lanka Red Cross Society, Care International etc.). These organizations are mainly involved in the activities related to supply of safe drinking water and provision of sanitation to the villages. Therefore, it was revealed that, improper agricultural practices and consequent water pollution are continued to take place, while having a plethora of government, non-government and farmer organizations having the mandate to control them. The study found that there is lack of continuous communication and integration among these institutions in the process of implementing the activities for the environmental conservation in Nuwara Eliya DS division. This is similar to the findings of Piyasiri (2008) that in Sri Lanka, the major problem in water resources management is lack of proper coordination between the institution.

\section{CONCLUSIONS AND RECOMMENDATIONS}

This study identified that the farmers in intensive agricultural areas in Nuwara Eliya apply overdoses of fertilizers and pesticides compared to the recommended levels of the Department of Agriculture. Beet crop has the highest over application rate of MOP which is about 16 times more than the recommended rate of Department of Agriculture. Carrot crop receives TSP about 5 times higher than the recommended rate by the Department of Agriculture. In addition, about $61 \%$ of the surveyed farmers who own their lands do not apply soil conservation methods. Poor awareness, small land parcels, lack of ownership, financial incapability are the identified reasons for non application of soil conservation methods. Loss of productive time of people due to travelling for long distances to fetch water, financial losses for cleaning and dredging of water resources, loss of income are some of the socio-economic problems identified as a result of agricultural pollution in the study area.

There are number of government and non government organizations working on agriculture and environmental related work in the area without a good coordination among their activities. As a result, environmental issues such as water pollution due to agriculture are idling without proper solutions. Since the agriculture based environmental and social problems are well understood, a collaborative effort should be formulated by these institutions to control excess usage of fertilizer and pesticides, promote healthy land management practices, build awareness among the farming community on the need of environmental conservation through eco-friendly farming activities etc. It is also important to identify environmental sensitive areas in Nuwara Eliya especially to control farming activities with the objective of protecting water resources.

A detailed study should be conducted to investigate why farmers apply fertilizers far more exceeding rates than those recommended by the Department of Agriculture and assess the residual impacts of the excess fertilizers. In addition, it is important to analyze the soils in the area to check the availability of plant nutrients and heavy metals in the soil profile. Residents and farmers of the area should be educated to maintain a good balance between agriculture and environment through best management practices. 


\section{REFERENCES}

Amarasiri, S. (2007). Declining Water Quality and its effect on Water Security, In: Water Resources Research in Sri Lanka, De Silva R.P. and Dayawansa N.D.K. (Ed.) Symposium proceedings of The Water Professionals' Day, Geo- Informatics Society of Sri Lanka (GISSL), pp 1-10.

Amarasekara, M.G.T.S., Kumarihamy, R.M.K., Dayawansa, N.D.K. and De Silva R.P. (2009). The impact of inappropriate soil management on river water quality: A case study in the Kurundu Oya sub catchment of the Upper Mahaweli Catchment, Sri Lanka, In: Food Security and Climate Change in Sri Lanka, Evans A and Jinapala K (Ed), Proceedings of the National Conference on Water, Food security and Climate Change, Volume 2, International Water Management Institute, Colombo, pp 49-60.

Amarathunga, A.A.D., Weerasekara K.A.W.S., Sureshkumar N., Shirantha R.R.A.R. and Azmy S.A.M. (2010). Total Suspended Solis and Turbidity Correlation in Kotmale Subcatchment of Mahaweli catchment, In: Water Resources Research in Sri Lanka, Dayawansa N.D.K. and De Silva R.P. (Ed.) Symposium proceedings of The Water Professionals' Day, Postgraduate Institute of Agriculture and Geo-Informatics Society of Sri Lanka, pp 115-124.

Ayers RS and Westcot D.W. (1985). Water quality for agriculture, Irrigation and Drainage, Paper no 29 (Rev. 1) FAO, Rome 174p.

Dayawansa, N.D.K. (2006). Water Pollution in Sri Lanka, Geo-Informatics Society of Sri Lanka.

Department of Agriculture (1997). Pesticide Recommendations 1997, Department of Agriculture, Sri Lanka

Department of Agriculture, Sri Lanka (DOASL) (2006). [online]. [Accessed on 2010/01/15] Available at http://www.agridept.gov.lk/sinhala/more.php

Department of Census and Statistics (2007). Household Income and Expenditure Survey 2005, Department of Census and Statistics, Colombo.

De Silva S. (2009). Water: A Root of poverty among estate women in Sri Lanka in Interfacing poverty, livestock and climate change in water resources development, Proceedings of the Fourth South Asia Water Research Conference, Nepal Engineering College, Chargunaryan, Bhaktapur, Nepal, pp 78-89.

EPA (US Environmental Protection Agency). (2005). Mancozeb Facts, [online]. [Accessed on 2011/05/10] Available at http://water.epa.gov.com

FAO. (1980). PROPINEB [online]. [Accessed on 25/05/2012]. Available at http://www.fao.org/ag/AGP/AGPP/Pesticid/Specs/docs/Pdf/old/Propineb.pdf

Gunawardena, E.R.N., Mahees, M.T.M., Gunawardene, I.P.P., Rathnapriya, Amarasekare, M.G.T.S. and Thrikawala, S. (2010). Transdisciplinary Research in Integrated Water Resources Management in Addressing Issues Related to Water Pollution of Mahaweli River, In: Symposium Proceedings of The Water Professional's Day, Edited by NDK Dayawansa and RP De Silva (Ed), GISSL. 
Mubarak, A.M. (2000). Water Pollution, In: Natural Resources of Sri Lanka, National Science Foundation, Colombo, Sri Lanka.

Piyasiri, S. (2008). Management of Inland waters of Sri Lanka with reference to 32 reservoirs, Proceedings of the symposium on Water: Research trends in Sri Lanka, compiled by Abeytunga D.T.U. and Randeniya P, Sri Lanka Association of Advancement of Science, Colombo, Sri Lanka.

Premarathna, H.M.P.L., Hettiarachchi, G.M. and Indraratne, S.P. (2005). Accumulation of Cadmium in Intensive Vegetable Growing Soils in the Up Country. Tropical Agricultural Research, 17: pp 93-103.

Rajakaruna, R.M.P., Nandasena K.A. and Jayakody A.N. (2005). Quality of Shallow Groundwater in an Intensively Cultivated Hilly Catena in Up Country Intermediate Zone of Sri Lanka, In: Water Resources research in Sri Lanka, Galagedara L.W. (Ed), Symposium Proceedings of the Water Professionals' Day, Postgraduate Institute of Agriculture, Sri Lanka, pp 163-178.

Ranathunga, N.U.K. and Ranasignhe, S.R. (2007). Water safety and portable water improvement in Nuwara Eliya District, In: Water Resources Research in Sri Lanka, De Silva R.P. and Dayawansa N.D.K. (Ed), Symposium Proceedings of The Water Professionals' Day, Geo-Informatics Society of Sri Lanka, pp 239-248.

Sri Lanka Land Reclamation and Development Corporation (SLLRDC) 2010, Lake Gregory Improvement Project-Phase I Dredging in Nuwara Eliya [online]. [Accessed on 2012/05/28] Available at http://www.landreclamation.lk/web/index.php?opt

Urban Development Authority (UDA) (1996). Nuwara Eliya Environmental Study; Environmental Action Plan, Volume 2, Roche International, Canada.

Urban Development Authority (UDA) (2004). Development Plan for Nuwara Eliya Urban Development Area (Nuwara Eliya Municipal Council area) 2004-2016, Volume 1, Situational Plan and Development Report.

Vigiak O., Ribolzi O., Pierret A., Valentin C., Sengtaheuanghoung, O. and Noble, A. (2007). Filtering of water pollutants by riparian vegetation: bamboo versus native grasses and rice in a Lao catchment, In: An international journal of forestry and forest industries [online]. [Accessed on 25/05/2012] Available at http://www.fao.org/docrep/010/a1598e/a1598e00.htm

Watawala, R.C., Liyanage, J.A., and Mallawatantri A.P. (2009). Assessment of Risks to water bodies due to residues of agricultural fungicide in intensive farming areas in the Upcountry of Sri Lanka using an indicator model, In: Food Security and Climate Change in Sri Lanka, Evans A and Jinapala K (Ed), Proceedings of the National Conference on Water, Food security and Climate Change, Volume 2, International Water Management Institute, Colombo, pp 69-75.

Wijewardena, J.D.H. (1998). Impact of Intensive Vegetable Cultivation on Drinking Water Quality in the Upcountry Region of Sri Lanka, In: Proceedings of the National Conference on Status and Future Direction of Water Resources in Sri Lanka, Samad, M., Wijesekera, N.T.S. and Birch, A. (Eds), pp 177-192 